Bohemica bellum tricennale illustrantia (7 vols., 1971-1981), brought him international acclaim. There and elsewhere, Polišenský exposed the intricate involvement of the English, French, Spanish, and Dutch in the rebellion of the Bohemian estates against the Habsburgs in 1618-1620 and its tragic aftermath, and he introduced a host of previously unused archival sources into the complicated nexus of historical issues and debates. He also maintained a lifelong interest in a major personality of the period, Comenius. The last in a continuous stream of Polišenskýs studies of his life and thought was Komenský, muż labyrintu a nadĕje (1996).

Polišenský was also seriously involved with three other major topics-the revolutionary changes in Europe in the first half of the nineteenth century and Anglo-American and Ibero-American history. To the first, he contributed two basic studies: Napoleon a srdce Evropy (1971) and Revoluce a kontrarevoluce v Rakousku 1848 (1975). He is rightly considered one of the pioneers of Czech study of the other two fields. He produced many survey histories of Great Britain, the United States, Spain, Portugal, and the countries of Latin America and more focused treatments of the historic ties between England and the Czech lands, Czech emigration to the United States, and Spanish and Portuguese expansion overseas.

A self-professed "workaholic," Polišenský-repeatedly hospitalized and almost totally blind in his last years-remained professionally active literally to his last day, drawing on his prodigious memory to dictate manuscripts and deliver oral presentations. His last foreign appearances were in Scotland in 1999 and in Texas and California in 2000. At the time of his death, a group of his American, British, and Czech colleagues were preparing to nominate him for an honorary foreign membership in the American Historical Association.

"Poli," as his friends called him, was a giant-a short, slight, gentle giant-insatiably passionate about history and unstintingly generous to those who sought his assistance. Cest jeho památce!

JOSEPH FREDERICK ZACEK State University of New York, Albany April 2001

\title{
Jörg K. Hoensch, 1935-2001
}

Jörg K. Hoensch's colleagues and friends were shocked by his sudden death on 24 February 2001 at the age of 65. Since 1972, Hoensch had held the chair in eastern European history at the University of the Saarland in Saarbrücken, and he had been a visiting professor in several institutions abroad, including Columbia University in 1976-1977.

Hoensch was born in Bruntál (Freudenthal) in Germanized northern Moravia on 8 September 1935. His father resettled the family in the American zone of Germany in 1947, where Hoensch completed his secondary education; he then studied in universities in Marburg/Lahn, Vienna, Bristol, and Tübingen. Hoensch received an M.A. from the University of California, Berkeley, in 1961, his Dr. Phil. at Tübingen in 1963, and his habilitation at Tübingen in 1972. His meticulous scholarship, command of foreign languages, and devotion to history won him assistantships at Tübingen with Dietrich Geyer and Werner Markert. After a brief docentship there, he was named to the chair in Saarbrücken. Since the 1960s, Jörg K. Hoensch has been recognized as one of the foremost historians of east central Europe and of Slovakia in particular. His many writings threw light on relatively unexplored chapters in the Slovak past and present.

Hoensch was elected a member of Collegium Carolinum in Munich and in 1995 joined the editorial board of its journal Bohemia. In 2000, he was elevated to coeditorship of Bohemia with Ferdinand Seibt and Hans Lemberg. On the occasion of his 65 th birthday in 2000, five colleagues at Collegium presented him with a Festgabe titled Studia Slovaca: Studien zur Geschichte der Slowaken und der Slowakei. It included twelve essays Hoensch had written from the 1960s to the 1990s and a bibliography of his publications: 15 mono- 
graphs, 88 journal essays, 11 edited and coedited books, and 5 contributions to major reference works. Among the essays included in the Festgabe is his admirable "The Slovak Republic, 1939-1945" (originally published in A History of the Czechoslovak Republic, 19181948, edited by Victor S. Mamatey and Radomír Luža, 1973). This and other studies on Slovakia distinguished Hoensch as the sole German historian of that time- and one of the few in the west-who tackled the contentious question of Slovakia's place in the Czechoslovak constitutional system and its breakaway in 1939 to form an independent state, and who dealt with it in an objective way based not on nationalistic or ideological fervor but on careful study of the evidence.

Hoensch's balanced scholarly approach can also be found in his other works: Die Slowakei und Hitlers Ostpolitik: Hlinkas Slowakische Volkspartei zwischen Autonomie und Separation 1938/1939 (1965); Geschichte der Tschechoslowakischen Republik (1966, 1978, 1992 with changed title); Der ungarische Revisionismus und die Zerschlagung der Tschechoslowakei (1967); Dokumente zur Autonomie-Politik der Slowakischen Volkspartei Hlinkas (1984); Das Scheitern der Verständigung. Tschechen, Deutsche and Slowaken in der Ersten Republik 1918-1938 (with Dušan Kováč, 1994; Czech original ,1993); Judenemanzipation-Antisemitismus-Verfolgung in Deutschland, Osterreich-Ungarn, den böhmischen Ländern und in der Slowakei (1999, with Stanislav Biman and L'ubomir Lipták; Slovak edition, 1999).

In their tribute volume, his German colleagues describe Hoensch's approach to teaching and scholarship as follows: "During his academic career, Hoensch displayed an ability to speak in polished phrases, and in addition to an enviably fine memory, he possessed above all the ability and energy to achieve outstanding results, always based on the latest scholarly research" (x).

In addition to his work on Slovakia, Hoensch's publications include many works concerned with Polish and Hungarian history and with medieval Central Europe, as well as the survey Geschichte Böhmens: Von der Slavischen Landnahme bis ins 20. Jahrhundert, which has been revised and updated three times $(1987,1992,1997)$ and deserves translation into English. He also wrote Geschichte Polens (1983, 1990, 1998), and Geschichte Ungarns 1867-1983 (English editions 1988, 1996). His Matthias Corvinus: Diplomat, Feldherr und Mäzen (1998) and Die Luxemburger: Eine spätmittelalterliche Dynastie gesamteuropäischer Bedeutung 1308-1438 (2000) further demonstrate his versatility and astounding productivity. Hoensch served on the UNESCO-launched German-Polish Schoolbook Commission, the German-Czech and the German-Slovak Historical Commissions, and other international cultural bodies. His death at the peak of his powers is a profound loss to the historical profession throughout the world.

STANLEY B. WinTERS New Jersey Institute of Technology April 2001

\section{Mirra Ginsburg, 1909-2000}

Mirra Ginsburg died on Long Island on 26 December 2000 at the age of 91 . She was born on 10 June 1909 in the Jewish town of Bobruisk, in Belarus. In the 1920s, her family emigrated to Canada and subsequently to the United States. Ginsburg spoke fondly of her childhood memories of living in a tightly knit, culturally conscious Jewish community of family and friends. As an adult, she lived and worked in New York as a freelance translator and served on translation juries. Ginsburg was a member of the American Literary Translators Association, Authors Guild, Authors League of America, and PEN.

My first meeting with Mirra Ginsburg in her apartment in 1975, on a dreadfully rainy day, was the beginning of a long friendship. I had read her brilliant translations of Aleksei Remizov and wanted to speak to her about the writer, who was the topic of my doctoral dissertation at Yale University. She had just received a Guggenheim Fellowship for her translation work, and my advisor, Victor Erlich, suggested I meet with her. As it turned out, we had so many interests in common that our conversation lasted for a quarter of a century. 